\title{
Studies on Preparation of Mango-Sapota Mixed Fruit Bar
}

\author{
R.F. Chavan ${ }^{1 *}$, V.G. Jadhao ${ }^{1}$ and B.K. Sakhale ${ }^{2}$ \\ ${ }^{1}$ Department of Agricultural Engineering, MIT, Aurangabad (MS) \\ ${ }^{2}$ Department of Chemical Technology, Dr. Babasaheb Ambedkar Marathwada University, \\ Aurangabad-431004, M.S., India \\ *E-mail: ramesh.chavaan@gmail.com
}

\begin{abstract}
The mixed fruit bars were prepared from sapota and mango pulp at different proportions viz. (0:100, 10:90, 20:80, $30: 70$ and 40:60) with sugar, citric acid (30 and 1\% citric acid by weight of pulp respectively) and evaluated the physico-chemical and sensory quality characteristics. All fruit bars were analyzed for their organoleptic characteristics such as color, flavor, taste, appearance and overall acceptability. The highly acceptable and desirable fruit bar with respect to color, taste, flavour, mouth feel and overall acceptability can be obtained with combination of 30 percent sapota pulp and 70 percent mango pulp. The product scored maximum score (8.1) for color, taste, flavor and overall acceptability.
\end{abstract}

Key words: Drying, fruit bar, mango, sapota, sensory evaluation.

Paper cited: Chavan, R.F., Jadhao, V.G. and Sakhale, B.K. (2016). Studies on preparation of mango sapota mixed bar. South Asian Journal of Food Technology and Environment, 2(2): 361-365.

\section{Introduction}

Fruit bars can be simply defined as dried sheets of fruit pulp that have a soft, rubbery texture and a sweet taste. These fruit bars are prepared by dehydrating fruit puree into a sheet. The edible portion of fruit is pulped, pureed, mixed with different ingredients to improve its physicochemical and sensory characteristics. These are then heated, formed and dried on flat trays until cohesive fruit bar is obtained. Fruit bars can be eaten as snack foods or added to a variety of food preparations (Raab and Oehler, 1999). The mango fruit is a rich source of vitamins and minerals. Mango accounts the highest among fruits for vitamin $\mathrm{C}$, vitamin $\mathrm{A}$, riboflavin, folate, calcium, thiamine, iron, niacin, potassium and fiber. The comparative low calorie content (32 kcal $/ 100 \mathrm{~g}$ of fruit) makes it a favourite fruit for obese people who are on a weight reducing regime (Liebman, 1992). Sapotas are one of the most consumed fruits worldwide and are consumed fresh or in processed forms such as jam, juice or dried. Due to the varied and well balanced composition of sapotas, they have the potential to prevent digestive cancers, colon and liver cancers, coronary heart disease, lung function disorder and asthma (Feliciano et al., 2010).

\section{Materials and Methods}

The present study was carried in the Agricultural Process Engineering Laboratory, Department of Agricultural Engineering, Maharashtra Institute of Technology, Aurangabad, Maharashtra. Fresh Mango (Mangifera indica) fruit cultivar of Kesar and Sapota (Manilkara zapota) fruit cultivar of Kalipatti were obtained from the local market of the Aurangabad city.

Extraction of pulp: Ripened sapotas were thoroughly washed with water, cut into pieces and passed through grinder-cum-mixer to obtain the fine pulp. The pulp was filtered through muslin cloth to remove fibrous materials and seeds. The mango pulp from the Kesar mango fruits was also extracted as per the process suggested by (Sakhale et al., 2012).

Preparation of fruit bar: The process of manufacturing the mango-sapota fruit bar was 
followed as per given in the (Fig.1). The different proportions were made in order to standardize the formulations (Chavan and Ingle, 2015). The standard formula for making the mango-sapota fruit bar has been given in (Table

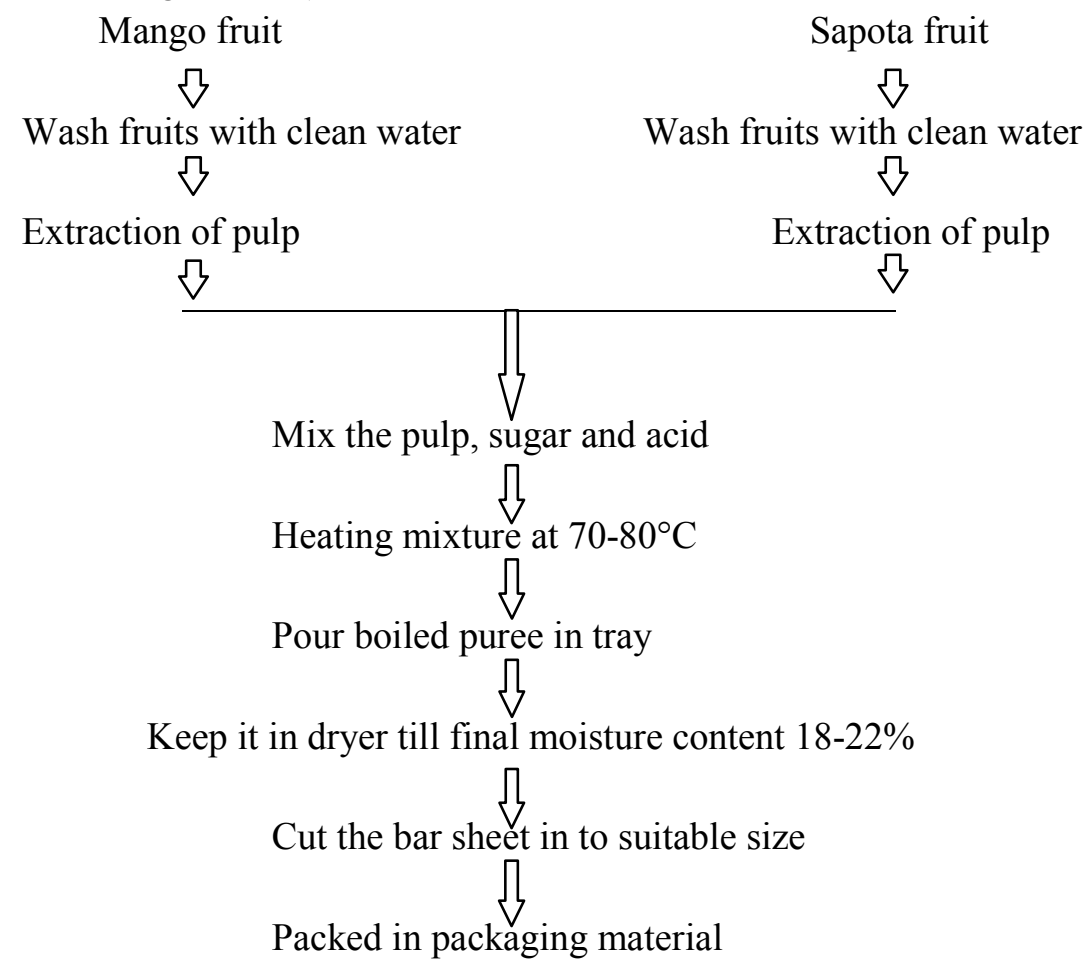

Fig.1: Flow Sheet for Preparation of Mango-Sapota fruit bar

Table 1: Standard Recipe for Formulation of Mango-Sapota Fruit Bar

\begin{tabular}{|l|c|c|c|c|c|}
\hline \multirow{2}{*}{ Ingredients } & \multicolumn{5}{|c|}{ Treatments } \\
\cline { 2 - 6 } & $\mathbf{C}_{\mathbf{0}}$ & $\mathbf{C}_{\mathbf{1}}$ & $\mathbf{C}_{\mathbf{2}}$ & $\mathbf{C}_{\mathbf{3}}$ & $\mathbf{C}_{\mathbf{4}}$ \\
\hline Sapota: mango (g) & $0: 100$ & $10: 90$ & $20: 80$ & $30: 70$ & $40: 60$ \\
\hline Sugar (g) & 20 & 20 & 20 & 20 & 20 \\
\hline Citric acid (g) & 1 & 1 & 1 & 1 & 1 \\
\hline
\end{tabular}

Physico-chemical analysis: The pulp of sapota and mango was evaluated for various physicochemical properties like moisture, TSS, $\mathrm{pH}$, acidity, ash, reducing sugars, total sugars, ascorbic acid, crude protein, crude fat and crude fiber. The fruit bars prepared with various combination of sapota and mango pulp were also evaluated for moisture, crude protein, fat, total sugars, acidity and ash content as per the
1). According to that fruit pulps of mango and sapota fruits were taken in different proportion in order to standardize the formulation (Revanwar and Sakhale, 2003).

Sapota fruit

clean water 
analyzed as per the methods given by (Panse and Sukhatme, 1985).

\section{Results and Discussion}

Formulation of mango-sapota mix fruit bar: After standardization of sugar-acid ratio the efforts were made to prepare sapota-mango mixed fruit bar. The sapota pulp was admixed with mango pulp at $10,20,30$, and 40 percent and evaluated for sensory analysis by panel members. Sincere efforts were made to prepare mixed fruit bar using sapota-mango pulp at various levels ranging from (0:100 to 40:60).
The sensory quality results are presented in (Table 1).

With increase in the level of sapota pulp in mixture reduced the color, flavor and taste score. It might be due to addition of higher level of sapota pulp proportionately decreased the mango pulp level in the mixture. This affects directly in reducing the appealing yellowish red color of the product and increase in dull color. Not only this, the higher sapota pulp in the mixture increases the breaking of bar texture in final bar but also lowers the overall acceptability of the products.

Table 2: Proximate composition of mango and sapota pulp*

\begin{tabular}{|l|c|c|}
\hline \multirow{2}{*}{\multicolumn{1}{|c|}{ Parameters }} & \multicolumn{2}{|c|}{ Composition } \\
\cline { 2 - 3 } & Mango Pulp & Sapota Pulp \\
\hline Moisture (\%) & 74.6 & 76.1 \\
\hline Protein (\%) & 0.49 & 1.06 \\
\hline Fat (\%) & 0.56 & 1.1 \\
\hline Total sugar (\%) & 16.8 & 17.4 \\
\hline Ash (\%) & 0.29 & 1.57 \\
\hline Fiber (\%) & 0.33 & 2.6 \\
\hline Reducing sugar (\%) & 10.2 & 5.2 \\
\hline T.S.S.( $($ Bx) & 16.1 & 19.4 \\
\hline Titrable acidity (\%) & 0.43 & 0.25 \\
\hline pH & 3.5 & 5.01 \\
\hline Ascorbic acid(mg/100g) & 22.3 & 9.8 \\
\hline
\end{tabular}

${ }^{*}$ Each value is the average of three determinations.

Physico-chemical properties: The results for physico-chemical composition of sapota and mango pulp are presented in (Table 2). The TSS content in sapota pulp was found higher $\left(19.4^{0}\right.$ Brix $)$ than in mango pulp $\left(16.1^{0} \mathrm{Brix}\right)$ but was less acidic $(0.25 \%)$ than mango pulp $(0.43 \%)$. The mango pulp was also rich in ascorbic acid content $(22.3 \mathrm{mg} / 100 \mathrm{~g})$ compared to sapota pulp which contained only 9.8 $\mathrm{mg} / 100 \mathrm{~g}$. The data on proximate composition of mixed fruit bar prepared from various blends of sapota and mango pulp showed a marked difference (Table 3).

The fruit bar prepared with different blends of sapota and mango pulp contained total sugar in the range between 77.23 to $79.12 \%$ and more acidic ( 0.78 to $0.87 \%)$ than the fruit bars prepared with either mango or sapota pulp. All the blends produced the fruit bars with comparable ash and protein contents. The fruit bar prepared from blend of (30:70), resulted protein content of $(1.5 \%)$. Both the fruits are 
good sources of sugars, ascorbic acid, crude fiber and reducing sugar.

Organoleptic Evaluation: The data presented in (Table 4) indicates that the fruit bar prepared from a blend of sapota and mango pulp at 30:70 ratio resulted into highest score in all the sensory quality parameters followed equally by a blend of 20:80. The color, taste, flavor, mouth feel and overall acceptability of this fruit bars were as good as to the fruit bar prepared from the single pulp of either fruit. However, the color, taste, flavor, mouth feel and overall acceptability scores of fruit bar prepared by a blend of 30:70 was comparatively higher than the fruit bars prepared from any of the blends. It might probably be due to synergistic effect of flavor of sapota and mango pulps.

Table 3: Proximate composition of mixed fruit bar

\begin{tabular}{|l|c|c|c|c|c|}
\hline \multicolumn{1}{|c|}{ Parameters } & $\mathbf{C}_{\mathbf{0}}$ & $\mathbf{C}_{\mathbf{1}}$ & $\mathbf{C}_{\mathbf{2}}$ & $\mathbf{C}_{\mathbf{3}}$ & $\mathbf{C}_{\mathbf{4}}$ \\
\hline Moisture (\%) & 17.26 & 16.78 & 16.63 & 16.58 & 16.54 \\
\hline Protein (\%) & 1.29 & 1.36 & 1.4 & 1.51 & 1.53 \\
\hline Fat (\%) & 0.69 & 0.71 & 0.73 & 0.72 & 0.75 \\
\hline Total sugars (\%) & 77.2 & 78.2 & 78.6 & 78.7 & 79.1 \\
\hline Titrable acidity (\%) & 0.78 & 0.83 & 0.84 & 0.86 & 0.87 \\
\hline Ash (\%) & 1.25 & 1.69 & 1.72 & 1.74 & 1.74 \\
\hline
\end{tabular}

$\mathrm{C}_{0^{-}}$Mango pulp $100 \%, \mathrm{C}_{1}$ - Sapota pulp $10 \%$ : mango pulp $90 \%, \mathrm{C}_{2}$ - sapota pulp $20 \%$ : mango pulp $80 \%$, $\mathrm{C}_{3}$-sapota pulp $30 \%$ : mango pulp $70 \%, \mathrm{C}_{4}$-sapota pulp $40 \%$ : mango pulp $60 \%$

Table 4: Sensory quality attributes of Mango-Sapota fruit bar

\begin{tabular}{|c|c|c|c|c|c|}
\hline $\begin{array}{c}\text { Blends of mixed } \\
\text { fruits pulp }\end{array}$ & Color & Appearance & Flavor & Taste & $\begin{array}{c}\text { Overall } \\
\text { Acceptability }\end{array}$ \\
\hline $\mathbf{C}_{\mathbf{0}}$ & 7.6 & 7.3 & 7.3 & 7.2 & 7.4 \\
\hline $\mathbf{C}_{\mathbf{1}}$ & 7.7 & 6.9 & 6.7 & 7.4 & 7.3 \\
\hline $\mathbf{C}_{\mathbf{2}}$ & 7.6 & 7.4 & 7.0 & 7.2 & 7.5 \\
\hline $\mathbf{C}_{\mathbf{3}}$ & 8.6 & 7.7 & 7.9 & 9.0 & 8.1 \\
\hline $\mathbf{C}_{\mathbf{4}}$ & 7.5 & 7.4 & 7.3 & 7.3 & 7.3 \\
\hline
\end{tabular}

$\mathrm{C}_{0}$ - Mango pulp $100 \%, \mathrm{C}_{1}$ - Sapota pulp $10 \%$ : mango pulp $90 \%, \mathrm{C}_{2}$ - sapota pulp $20 \%$ : mango pulp $80 \%$, $\mathrm{C}_{3}$-sapota pulp $30 \%$ : mango pulp $70 \%, \mathrm{C}_{4}$-sapota pulp $40 \%$ : mango pulp $60 \%$

\section{Conclusion}

The highly acceptable and desirable products with respects to colour, taste, flavour and overall acceptability can be obtained with combination of 30 per cent sapota pulp and 70 per cent mango pulp. The mixed fruit bars prepared from sapota and mango pulp at different proportions were found almost similar with respect to proximate composition. With increase in the level of sapota pulp in mixture reduced the overall acceptability value, hence higher level of sapota pulp in mango pulp is not desirable from overall acceptability point of view. Therefore the best recommendable ratio of 
sapota-mango pulp for excellent quality mixed fruit bar is 30:70.

\section{References}

1. Amerine, M.S., Pangborn, R.M. and Roessler, E.A. (1965). Principles of sensory evaluation of foods. Academic Press, New York.

2. Chavan, R.F. and Ingle, M.P. (2015). Studies on formulation of papaya-apple mixed fruit leather and drying characteristics of apple and papaya fruits. Beverage and Food World, 42(9): 44-46.

3. Feliciano, R.P., Antunes, C., Ramos, A., Serra, A.T., Sapotaueira, M.E., Duarte, M.M., de Carvalho, A., Bronze, M.R.(2010).Characterization of traditional and exotic sapota varieties from Portugal. J. Funct. Foods, 2: 35-45.

4. Liebman, B. (1992). A mango a day nutrition action health letter. Nutrition action health letter".
5. Panse, V.G. and Sukhatme, P.V. (1985). Statistical Method for Agricultural Workers.

6. Raab, C. and Oehler, N. (1999). Making dried fruit leather fact sheet. Oregon State University Extension Service. USA Fact Sheet, 232: 1-4

7. Ranganna, S. (2000). Handbook of Analysis and Quality Control for Fruits and Vegetable products, $2^{\text {nd }}$ edition, Tata McGraw Hill Publ. Co.; New Delhi.

8. Revanwar, D.S. and Sakhale, B.K. (2003). Studies on preparation and recipe standardization of papaya toffee. Beverage Food World, 33(10): 42-44.

9. Sakhle, B.K., Pawar, V.N. and Ranveer, R.C. (2012). Studies on the development and storage of whey based RTS beverage from Mango cv. Kesar. Journal of Processing and Preservation, 3(3):1-4. 